\title{
Pharmacokinetics and pharmacodynamics of natalizumab in pediatric patients with RRMS
}

Angelo Ghezzi, MD, Giancarlo Comi, MD, Luigi Maria Grimaldi, MD, Lucia Moiola, MD, Carlo Pozzilli, MD, Simone Fantaccini, MD, and Paolo Gallo, MD

Neurol Neuroimmunol Neuroinflamm 2019;6:e591. doi:10.1212/NXI.0000000000000591

\section{Abstract}

\section{Objective}

This phase I study investigated pharmacokinetic (PK) and pharmacodynamic (PD) profiles of natalizumab in pediatric patients with relapsing-remitting MS (RRMS).

\section{Methods}

Pediatric patients with RRMS who were prescribed natalizumab $300 \mathrm{mg}$ IV every 4 weeks were enrolled. Blood samples were collected on days 1, 2, 8, 15, and 22 and at weeks 4, 8, 12, and 16 to estimate PK parameters; PD properties were evaluated by measuring a4-integrin saturation and lymphocyte counts over time. Natalizumab's safety profile was also evaluated.

\section{Results}

PK parameters were similar to those reported in adult patients; natalizumab concentrations peaked approximately 1 day after infusion in most of the participants (Cmax $142.9 \mu \mathrm{g} / \mathrm{mL}$, AUClast $47389.4 \mathrm{hr}^{*} \mu \mathrm{g} / \mathrm{mL}$ ), followed by a biphasic decline with a rapid distribution phase and a slow elimination phase, with a terminal half-life of 215.1 hours. In terms of PD, both time course and magnitude of $\alpha 4$-integrin saturation and increase in lymphocyte counts were similar to those observed in adults. During the 16-week study follow-up, 3 adverse events attributed to natalizumab were observed; no unexpected safety events occurred.

\section{Conclusions}

PK profile, a4-integrin saturation, lymphocyte counts, and safety observed in these pediatric patients are comparable to those reported in adults.

\section{Classification of evidence}

This study provides Class I evidence that natalizumab PK/PD parameters and safety profile are similar in adults and pediatric patients in the short term. Longer studies, also including a larger number of younger subjects (aged 10-12 years), are required to further inform about long-term $\mathrm{PK}$ and PD parameters in pediatric patients with MS.

\author{
Correspondence \\ Dr. Ghezzi \\ angelo.ghezzi@asst-valleolona.it
}

\section{MORE ONLINE}

$\rightarrow$ Class of Evidence

Criteria for rating

therapeutic and diagnostic

studies

NPub.org/coe 


\section{Glossary}

$\mathbf{A E}=$ adverse event; IFN = interferon; IVI = IV immunoglobulin; PD = pharmacodynamic; PK = pharmacokinetic; PML = progressive multifocal leukoencephalopathy; RRMS = relapsing-remitting MS; SAE = severe AE.

Natalizumab (Tysabri; Biogen, Cambridge, MA), a recombinant humanized anti- $\alpha 4$-integrin antibody, has proven to be efficacious for the reduction of clinical progression in adult patients with relapsing-remitting MS (RRMS) ${ }^{1-3}$ Following the results of pivotal trials, natalizumab $300 \mathrm{mg}$ IV every 4 weeks has been approved in Europe for the treatment of RRMS in adult patients. ${ }^{4}$ This molecule is not indicated for patients aged $<18$ years; pediatric usage is off label, almost exclusively as second line, ${ }^{5-9}$ primarily because of safety concerns. ${ }^{10-12}$ However, in Italy, natalizumab use is allowed in adolescents aged 12-18 years with active MS and for whom no other alternative treatments are available (according to the Italian Law 648/96 $\left.{ }^{13}\right)$.

The adult dose ( $300 \mathrm{mg}$ IV every 4 weeks) seems to be well tolerated and effective in reported case series of pediatric patients, ${ }^{8,11,14-23}$ and based on postmarketing safety reporting, including 2 retrospective studies on 29 pediatric patients and 2 registries comprising 133 participants, the adverse event $(\mathrm{AE})$ profile appears to be similar between the pediatric and the adult population. ${ }^{19-22}$ Moreover, no apparent pharmacokinetic (PK) differences have been reported between adult and pediatric patients with Crohn disease treated with comparable natalizumab doses, thus suggesting that disposition of natalizumab is not likely to change with age. ${ }^{23}$ Last, global data from observational studies ${ }^{7,9,24}$ and national registries ${ }^{21,22}$ suggest that natalizumab $300 \mathrm{mg}$ IV every 4 weeks is effective and well tolerated in pediatric patients with MS (majority aged $\geq 10$ years).

Although information on the safety of natalizumab in pediatric patients seems to be in line with that of adult patients, ${ }^{19-22}$ evidence on the PK and pharmacodynamic (PD) profile of natalizumab in this specific patient population is still scant and would be necessary to further extend the use of this molecule to pediatric patients.
Moreover, these studies would provide important information on the use of new medications in the pediatric MS population. ${ }^{22,25-27}$ This phase I study was designed to determine the $\mathrm{PK}$ and $\mathrm{PD}$ profile of natalizumab in pediatric patients with RRMS.

\section{Methods}

\section{Study setting and design}

This was an open-label, multiple-dose, multicenter prospective study to evaluate the PK/PD profile, safety, and tolerability of natalizumab $300 \mathrm{mg}$ every 4 weeks administered IV to male and female pediatric patients (aged 10-18 years at the time of informed consent) with RRMS.

Figure 1 summarizes the study design. Participants attended clinic visits on days $1,2,8,15$, and 22 and at weeks 4, 8, 12, and 16 to complete assessments. A follow-up contact by telephone at 12 weeks ( \pm 2 weeks) after the last infusion of study treatment was required for patients who received $\geq 1$ infusion of study treatment and who did not continue treatment with natalizumab in the Italian National Registry (see below).

\section{Standard protocol approvals, registrations, and patient consents}

Patients were included in the study after they and their parents signed the informed consent. The study has been approved by the ethics committee of the coordinating center and by all the sites that participated to the study. Trial registration number: $101 \mathrm{MS} 328$.

\section{Patients}

Patients were eligible to participate in the study if they met the following criteria: (1) age 10-18 years; (2) diagnosis of rapidly evolving severe RRMS (defined by 2 or more disabling

Figure 1 Study design

Screening (4 weeks)

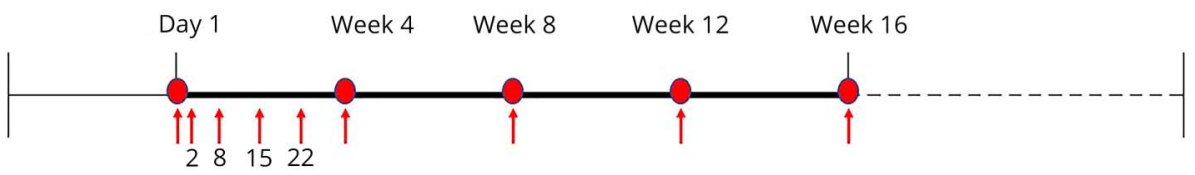

Natalizumab infusion

$\uparrow$ Visit + PK/PD sample

Treatment (16 weeks) Continuation of treatment*
*Subjects who complete the PK/PD study through Week 16 and for whom continue treatment with natalizumab is prescribed by their treating physician may continue treatment with natalizumab in the Italian National Registry. PD = pharmacodynamic; $\mathrm{PK}=$ pharmacokinetic. 
relapses in 1 year) and 1 or more gadolinium (Gd)-enhancing lesions on brain MRI or a significant increase in T2 lesion load compared with a previous recent MRI; (3) natalizumab treatment deemed appropriate by the treating physician; and (4) agree to the use of contraceptives if the participant is sexually active.

Exclusion criteria were as follows: (1) any potential differential diagnosis other than pediatric-onset RRMS; (2) any major infection (HIV, Hepatitis C virus, and Hepatitis B virus); (3) any major illness (progressive multifocal leukoencephalopathy $[\mathrm{PML}])$, inflammatory disorders, metabolic neurogenetic leukodystrophies, toxic leukoencephalopathies, vascular conditions, malignancies, neurologic/psychiatric conditions, and severe allergic or anaphylactic reactions); (4) known drug hypersensitivity; (5) MS relapse within 30 days before enrollment; (6) abnormal laboratory values, absolute lymphocyte count, hemoglobin, platelet count, serum creatinine, alanine aminotransferase, aspartate aminotransferase, gamma glutamyltransferase, bilirubin, or any abnormal laboratory values indicative of significant medical, neurologic-other than MS—or psychiatric disorders); (7) previous treatment with natalizumab, lymphoid irradiation, cladribine, mitoxantrone, fingolimod, teriflunomide, $\mathrm{T}$ cell or T-cell receptor vaccination, cyclophosphamide, cyclosporine, azathioprine, methotrexate, mycophenolate, mofetil, or any therapeutic monoclonal antibody or immunoglobulins, corticosteroids or immunosuppressive/immunomodulatory therapy, plasmapheresis, or cytapheresis within 12 months before the first infusion of study treatment; and (8) participation in any other investigational study. The following concomitant treatments were also disallowed and could lead to patient's exclusion if administered during the course of the study: alternative immunotherapy or immunosuppressant therapy, any investigational product, any systemic steroids (apart from short courses of high-dose corticosteroids for exacerbation of MS disease), total lymphoid irradiation, cladribine, $\mathrm{T}$ cell or $\mathrm{T}$-cell receptor vaccination, any therapeutic monoclonal antibody, mitoxantrone, cyclosporine, IV immunoglobulin (IVIg), plasmapheresis, or cytapheresis.

\section{Treatment and assessments}

Eligible patients who entered the study received natalizumab $300 \mathrm{mg}$ IV every 4 weeks for 16 weeks for a total of 5 doses. Blood samples were collected on days 1, 2, 8, 15, and 22 and at Weeks 4, 8, 12, and 16 to estimate PK parameters from natalizumab concentrations. At least 12 patients, including at least 5 females, were planned to be enrolled.

Blood samples to determine natalizumab concentrations were collected from day 1 through the week 16 visit (for detailed timeline, see figure 1) to measure the following: maximum observed concentration (Cmax); minimum observed concentration (Cmin); predose (trough) serum concentration (Cpredose); time to reach maximum observed concentration (Tmax); area under the concentration-time curve from time zero to infinity (AUCinf); area under the concentration-time curve to the last measurable concentration as measured by the trapezoidal rule (AUClast); clearance; volume of distribution; and elimination half-life $\left(\mathrm{t}^{1 / 2}\right)$.

The following tests were performed to assess the PD properties of natalizumab: (1) a4-integrin saturation and (2) lymphocyte counts.

The following clinical assessments were performed to assess the safety profile of natalizumab: $\mathrm{AE}$ and severe $\mathrm{AE}(\mathrm{SAE})$, according to the common terminology criteria for AEs, version 4.0; physical and neurologic examinations; vital sign measurements; weight and height; and concomitant therapy and procedures. Complete laboratory assessments were also performed. Last, immunogenicity assessments (antinatalizumab antibody status) were performed to assess the safety of natalizumab at baseline and at the time of last infusion. All data were analyzed by descriptive statistics, using Microsoft Excel software.

\section{Italian National Registry}

Patients who completed the PK/PD study were expected to enroll in the Italian National Registry. This was limited to adolescents aged between 12 and 18 years who fall in the characteristics of "group B" of the Italian National Registry (patients with rapidly evolving severe RRMS as defined above). Patients who enrolled in the Italian National Registry received commercial natalizumab in accordance with any related pharmacovigilance recommendations as described in the prescribing information.

\section{Data availability}

Study protocol and anonymized individual participant data collected during the trial are available by request via the Biogen Clinical Data Request Portal (biogenclinicaldatarequest.com). Data access will be available upon approval for qualified scientific researchers who provide a methodologically sound research proposal. To gain access, data requestors will need to sign a data-sharing agreement.

\section{Results}

\section{Patients}

A total of 13 pediatric patients with RRMS were enrolled, and all of them completed the study; no participant withdrew before dosing, and no one discontinued natalizumab treatment or withdrew from the study for any reason. All 13 patients entered the Italian National Registry at the end of the study.

Patients' baseline characteristics are shown in table 1. Median age was 16 years (range, 11-17 years). The majority of the participants $(n=9)$ were older than 13 years. Ten patients (77\%) were female. Mean weight and height were $59.1 \mathrm{~kg}$ $( \pm 12.7 \mathrm{~kg})$ and $162.4 \mathrm{~cm}( \pm 7.8 \mathrm{~cm})$, respectively. Mean body mass index was $22.2 \mathrm{~kg} / \mathrm{m}^{2}\left( \pm 3.710 \mathrm{~kg} / \mathrm{m}^{2}\right)$. 
Table 1 Patient and disease characteristics

Patients enrolled

$(n=13)$

\begin{tabular}{ll}
\hline Sex $[\mathbf{n}(\%)]$ & $3(23 \%)$ \\
\hline Male & $10(77 \%)$ \\
\hline Female & $16(11-17) y$ \\
\hline Age [mean (range)] & $13(100 \%)$ \\
\hline Ethnicity [n (\%)] & \\
\hline White & $59.1 \pm 12.7$ \\
\hline Weight (kg) & $58.0(42,84)$ \\
\hline Mean \pm SD & $162.4 \pm 7.8$ \\
\hline Median (range) & $160.0(155,183)$ \\
\hline Height (cm) & $22.2 \pm 3.71$ \\
\hline Mean \pm SD & $22.31(16.8,28.9)$ \\
\hline Median (range) & \\
\hline BMI (kg/m ${ }^{2}$ ) & \\
\hline Mean \pm SD & \\
\hline Median (range) & \\
\hline Anti & \\
\hline
\end{tabular}

\section{Anti-JCV antibody}

\begin{tabular}{ll}
\hline Positive & $7(54 \%)$ \\
\hline Negative & $6(46 \%)$
\end{tabular}

\begin{tabular}{ll}
\hline MS diagnosis, mean (range) & \\
\hline Time from onset & $1.0(0-5) \mathrm{y}$ \\
\hline Age at onset & $14.0(10-17) \mathrm{y}$ \\
\hline Time from diagnosis & $1.0(0-5) \mathrm{y}$ \\
\hline Age at diagnosis & $14.2(10-17) \mathrm{y}$
\end{tabular}

\begin{tabular}{ll}
\hline Relapses, mean (range) & \\
\hline No. relapses-past $\mathbf{1 2}$ months & $1.9(1-3)$ \\
\hline No. relapses-past $\mathbf{2}$ years & $2.5(1-5)$ \\
\hline Time since last relapse & $3.0(1-6)$ mo \\
\hline MRI at inclusion & $3(23 \%)$ \\
\hline Gd+ administration in the last mo [n (\%)] & $1.8 \pm 2.3$ \\
\hline Gd+ lesions (mean \pm SD) & $1(8 \%)$ \\
\hline $\mathbf{0}$ & $11(85 \%)$ \\
\hline $\mathbf{1 - 5}$ & $1(8 \%)$ \\
\hline $\mathbf{6 - 1 0}$ & $10.7 \pm 8.9$ \\
\hline New or enlarging T2 lesions (mean \pm SD) & $2 / 10(20 \%)$ \\
\hline$\leq \mathbf{1}$ & $1 / 10(10 \%)$ \\
\hline$>\mathbf{1 - 5}$ & $2 / 10(20 \%)$ \\
\hline$>\mathbf{5 - 1 0}$ & $3 / 10(30 \%)$ \\
\hline$>\mathbf{1 0 - 1 5}$ & \\
\hline
\end{tabular}

Table 1 Patient and disease characteristics (continued)

\begin{tabular}{|c|c|}
\hline & $\begin{array}{l}\text { Patients enrolled } \\
(n=13)\end{array}$ \\
\hline$>15-20$ & 0 \\
\hline$>20-25$ & $2 / 10(20 \%)$ \\
\hline \multicolumn{2}{|l|}{ Medical history [n (\%)] } \\
\hline Neurologic & $13(100 \%)$ \\
\hline Allergy & $2(15 \%)$ \\
\hline Heent & $2(15 \%)$ \\
\hline Dermatologic & $1(8 \%)$ \\
\hline Gastrointestinal & $1(8 \%)$ \\
\hline Genitourinary & $1(8 \%)$ \\
\hline Endocrine/metabolic & $1(8 \%)$ \\
\hline Musculoskeletal & $1(8 \%)$ \\
\hline Infectious disease & $1(8 \%)$ \\
\hline \multicolumn{2}{|l|}{ Previous treatment, $\mathrm{n}(\%)$} \\
\hline$\geq 1$ treatment & $7(54 \%)$ \\
\hline IFN $\beta-1 a$ & $5(48 \%)$ \\
\hline GA & $1(8 \%)$ \\
\hline IVIg + IFN $\beta-1 b$ & $1(8 \%)$ \\
\hline \multicolumn{2}{|c|}{ Treatment discontinuation } \\
\hline Lack of efficacy & $6(48 \%)$ \\
\hline Intolerability & $1(8 \%)$ \\
\hline \multicolumn{2}{|c|}{$\begin{array}{l}\text { Abbreviations: } \mathrm{BMI}=\text { body mass index; } \mathrm{GA}=\text { glatiramer acetate; } \mathrm{Gd}= \\
\text { gadolinium; Heent = head, eyes, ears, nose, and throat, IFN = interferon; IVIg } \\
=\text { IV immunoglobulin; JCV = JC virus. }\end{array}$} \\
\hline
\end{tabular}

Table 1 also summarizes participant's disease characteristics. The median time since the onset of first MS symptoms was 1.0 years (range, $0-5$ years), and the median time since the diagnosis of MS was 1.0 years (range, $0-5$ years). The mean age at the onset of MS symptoms was 14.0 years ( \pm 2.6 years), and the mean age at the diagnosis of MS was 14.2 years $( \pm 2.6$ years). All participants had experienced at least 1 relapse in the past 12 months before enrollment. The mean number of Gd-enhancing lesions observed in MRI for study inclusion was $1.8( \pm 2.3)$, with the majority $(85 \%)$ of the patients having between 1 and $5 \mathrm{Gd}$ enhancing lesions.

Seven patients had received at least 1 previous treatment for MS; most patients had received interferon $\beta$-1a (IFN $\beta$-1a), 1 patient had received glatiramer acetate, and 1 patient had received IVIg and IFN $\beta$-1b. Six of the 7 patients had stopped their previous treatment because of efficacy reasons, and 1 patient had stopped the previous treatment because of intolerability (table 1). 


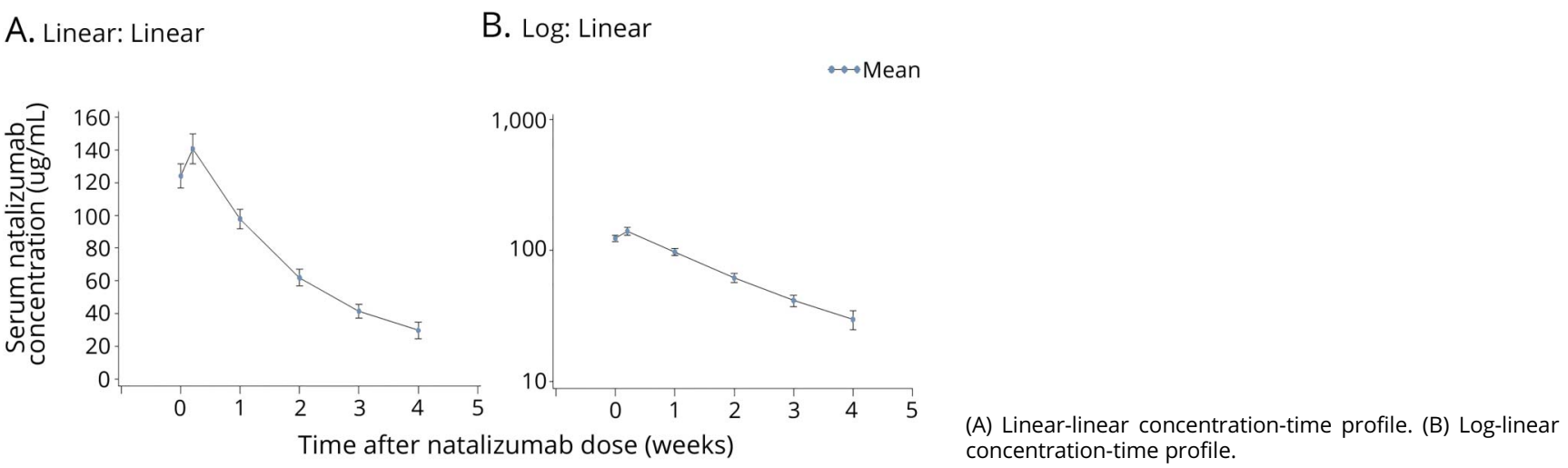

\section{Exposure to study treatment}

No participant missed a scheduled dose of natalizumab, and all patients received the full $300 \mathrm{mg}$ dose. The median time between infusions was 28 days (range, 24-33 days), and the median time on study was 16.1 weeks (range, 16.1-17.0 weeks). There were no major protocol deviations that concerned the administration of a dose to a patient.

\section{PK assessment}

A mean number of 13 samples were measured for natalizumab concentrations at each time points. A summary of serum natalizumab concentrations is presented in table e-1 (links. lww.com/NXI/A125), and a summary of serum natalizumab concentrations by age group is presented in table e- 2 .

Following administration of the first natalizumab dose, the median Tmax was 24.7 hours (range, 1.1-29.0 hours). The maximum serum natalizumab concentration was observed to occur in most of the patients (8/13) approximately 1 day postinfusion and in 5 patients at the end of infusion (within 15 minutes of the end of the infusion). The percentage difference in concentrations measured 24 hours postinfusion, compared with the end of infusion, ranged between $4 \%$ and $123 \%$.

The geometric mean exposure to natalizumab as estimated by Cmax was $142.9 \mu \mathrm{g} / \mathrm{mL}$ and by AUClast was $47389.4 \mathrm{hr}{ }^{*} \mu \mathrm{g} / \mathrm{mL}$. Variability in exposure, as measured by Cmax and AUClast, was low to moderate for natalizumab, with coefficients of variance of $18.49 \%$ and $26.88 \%$, respectively.

The natalizumab concentration-time profile after peak concentration exhibited a biphasic decline with a rapid distribution phase and a slow elimination phase. The inflection between the 2 phases occurred at approximately 8-15 days postdose (figure 2). Natalizumab was eliminated with a geometric mean terminal half-life $\left(\mathrm{t}^{1} / 2\right)$ of 215.1 hours. Half-life could not be estimated in 4 of 13 participants, as the terminal elimination phase could not be adequately characterized.

Figure 3 Mean trough (preinfusion) serum natalizumab concentrations
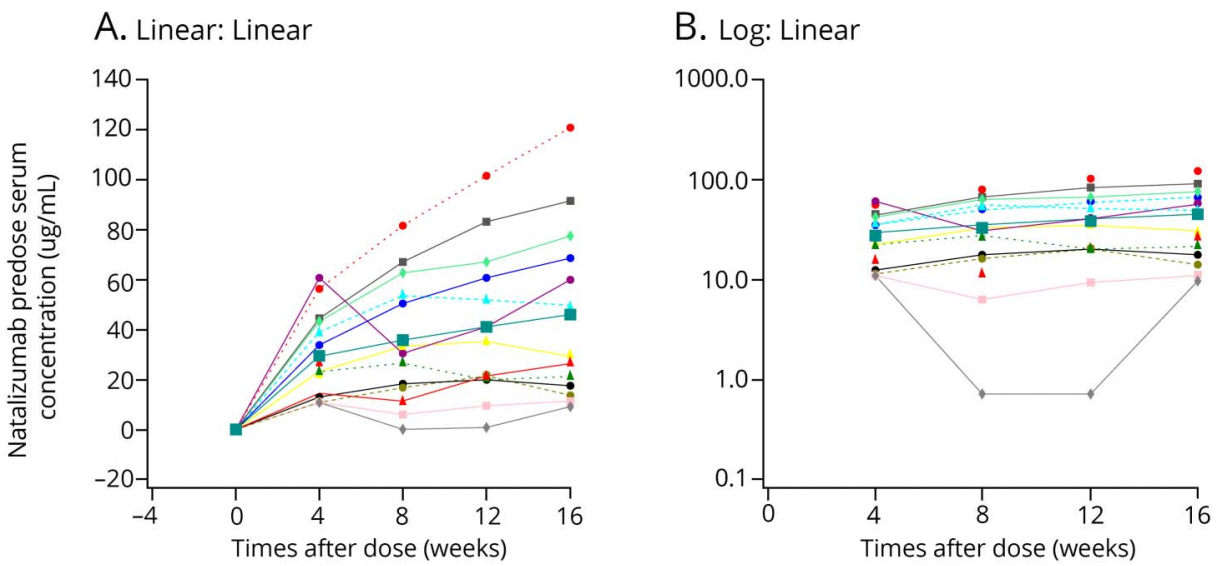

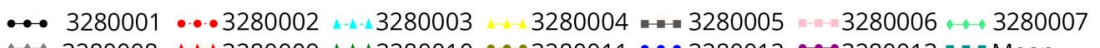

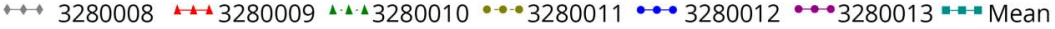




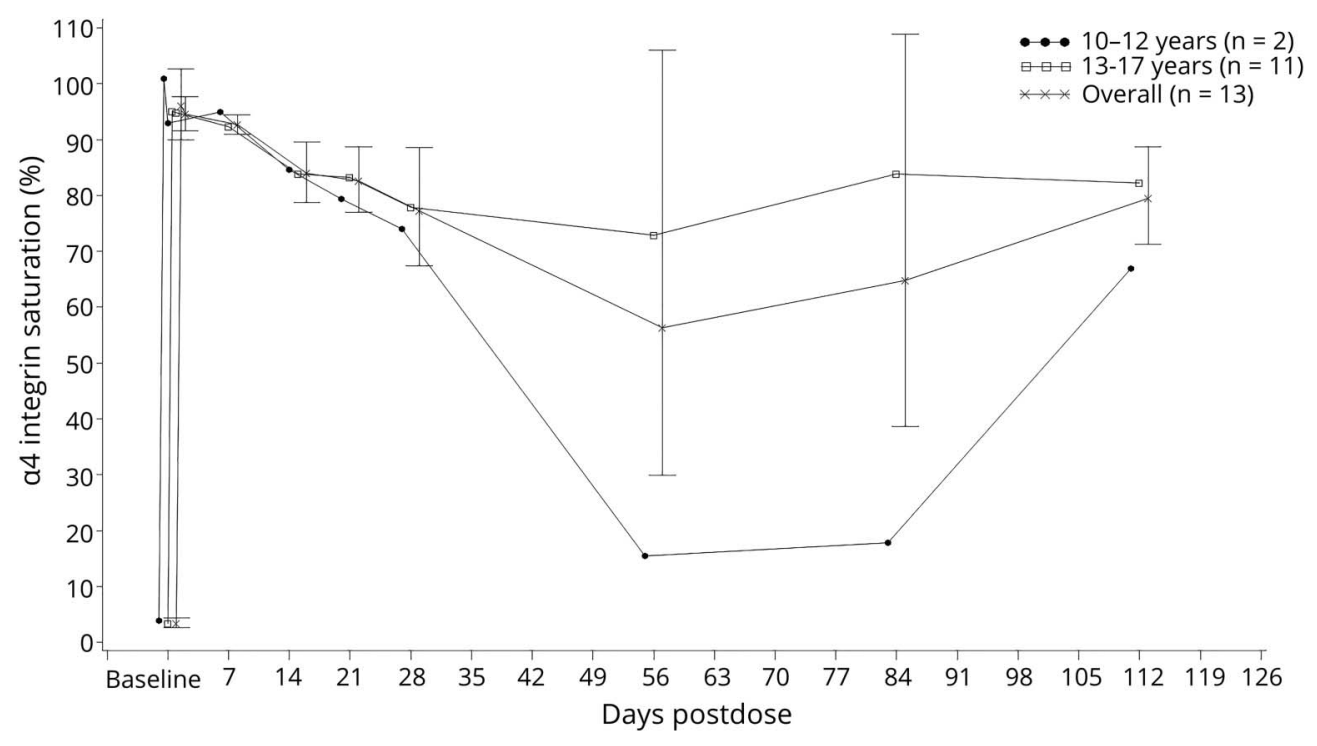

Qualitative inspection of mean trough (preinfusion) serum natalizumab concentrations suggests that steady-state concentrations were not reached by week 16 (figure 3 ).

\section{PD assessment}

Figure 4 depicts the geometric mean of $\alpha 4$-integrin saturation over time. Peak a4-integrin saturation occurred within 15 minutes following the first infusion (week 1) of natalizumab. Saturation remained elevated with mean Cmin values at or above $72.1 \%$ through week 16 .

Lymphocyte counts increased over time, sharply increasing from a mean baseline value of $1.86 \times 10^{9}$ cells $/ \mathrm{L}$ to $3.48 \times 10^{9}$ cells/L by week 4 and rising more slowly to $4.03 \times 10^{9}$ cells $/ \mathrm{L}$ by week 16. Overall, this elevation was greater than $110 \%$ increase over baseline counts.

\section{Safety assessments}

Table 2 summarizes the overall incidence of AEs. Of the 13 patients who received at least 1 dose of study treatment, 10 (77\%) experienced at least 1 AE. Three patients (23\%) experienced an $\mathrm{AE}$ that was assessed as related to natalizumab treatment; these AEs were in detail: upper respiratory tract infection $(n=1)$, asthenia $(n=1)$, and headache and nausea $(n=1)$. None of the patients experienced increase in liver enzyme, acute infusion-related hypersensitivity reactions, or development of PML. Of note, table e-3 (links.lww.com/ NXI/A125) summarizes mean lymphocyte counts by age group throughout the study.

Two patients (15\%) experienced an AE of moderate intensity. No SAE was observed. Only 1 patient (8\%) experienced a serious $\mathrm{AE}$; this patient was hospitalized for evaluation of dizziness, but no cause was identified. This SAE was assessed as not related to natalizumab treatment by the investigator, and the patient's symptoms resolved within 2 days. Antinatalizumab antibodies were not observed at any of the sampled time points for immunogenicity.

Table 2 Incidence of AEs

\begin{tabular}{|c|c|}
\hline & $\begin{array}{l}\text { Patients, } \\
\text { n (\%) }\end{array}$ \\
\hline AEs & $10(77 \%)$ \\
\hline Infection and infestation & $5(38 \%)$ \\
\hline Psychiatric disorders & $2(15 \%)$ \\
\hline Nervous system disorders & $6(46 \%)$ \\
\hline Cardiac disorders & $1(8 \%)$ \\
\hline Gastrointestinal disorders & $2(15 \%)$ \\
\hline Musculoskeletal and connective tissue disorders & $3(23 \%)$ \\
\hline $\begin{array}{l}\text { General disorders and administration site } \\
\text { conditions }\end{array}$ & $2(15 \%)$ \\
\hline Injury, poisoning, and procedural complications & $1(8 \%)$ \\
\hline Adverse drug reactions & $3(23 \%)$ \\
\hline Infection and infestation & $1(8 \%)$ \\
\hline Nervous system disorders & $1(8 \%)$ \\
\hline Gastrointestinal disorders & $1(8 \%)$ \\
\hline $\begin{array}{l}\text { General disorders and administration site } \\
\text { conditions }\end{array}$ & $1(8 \%)$ \\
\hline Serious AEs & $1(8 \%)$ \\
\hline Premature discontinuations & 0 \\
\hline
\end{tabular}

Abbreviation: $\mathrm{AE}$ = adverse event. 


\section{Discussion}

The present study has provided useful information on the PK/PD profile of natalizumab administered to RRMS children and adolescents. PK parameters (AUC and Cmax) following the administration of the first natalizumab dose and of trough concentrations ( $\mathrm{Cmin}$ ) at week 12 in pediatric patients were similar to those reported in studies with adult patients (Study 101MS102 [NCT00559702], Study C-1801 [NCT00027300], and Study C-1802 [NCT00030966]) indicating an overlap of PK parameters between the 2 populations. Although the number of evaluated patients was low, at each time point, there were no major differences in natalizumab concentrations between the 2 pediatric patients aged $10-12$ years and the 11 patients aged 13-17 years. The similarity in natalizumab PK profile between pediatric and adult patients is further confirmed by the fact that steady state was not reached by week 16 in the pediatric population; similarly, in adult patients, the predicted time to steady state was approximately 36 weeks. ${ }^{28}$ Moreover, similarly to adults, this pediatric population showed an interindividual variability in natalizumab concentrations. We acknowledge that the number of patients included in the study was small (especially for younger subjects, as only 2 patients aged between 10 and 12 years were included) and that the CIs recorded were wide. The concentration of serum natalizumab observed in this study has several deviations both above and below the therapeutic range predicted for adult patients: based on the Emax model, natalizumab serum concentrations of approximately $2.5-3 \mu \mathrm{g} / \mathrm{mL}$ would be required to maintain a minimum $a 4$-integrin saturation of $80 \% .{ }^{29}$ As expected from studies with adult patients with $\mathrm{MS}^{30,31}$ peak a4-integrin saturation occurred shortly ( $\leq 15$ minutes) after the first infusion of natalizumab, and saturation remained elevated during the study. A decrease of a4integrin saturation was observed at the time of the 3rd and 4th administration in the 2 subjects with less than 12 years. Further studies may clarify whether this pattern is specifically related to the younger age or reflects the normal variability observed in adults and the relationship between lower concentrations of natalizumab and a4-integrin saturation.

Mean lymphocyte counts increased over time, especially from baseline to week 4 and subsequently at a lower rate between week 4 and week 16 . Overall, the time course and magnitude of $a 4$-integrin saturation and the change in lymphocyte counts in these pediatric patients with MS were consistent with the results seen in studies with adult patients.

In terms of safety, natalizumab administration proved to be safe in pediatric patients, and all AEs observed were consistent to the known safety profile of the drug, with the most common AEs occurring in the System Organ Classes of nervous system disorders, infections and infestations, and musculoskeletal and connective tissue disorders. The frequency and severity of AEs were similar to those seen in adult patients; only 1 patient reported a serious $\mathrm{AE}$ (dizziness) that occurred 24 days after the previous infusion of natalizumab and was assessed by the investigator as mild in severity and not related to natalizumab treatment. There were no discontinuations of treatment, withdrawals due to AEs, and no acute infusionrelated hypersensitivity reactions reported in the study. Moreover, the immunogenicity assessment showed no production of anti-natalizumab antibodies at week 16 for all the treated patients. Of note, the safety profile of natalizumab was not adversely affected by the slight increased exposure, in terms of serum concentrations of natalizumab, observed during the study.

Although larger studies are necessary to confirm the abovereported findings, based on the results of this study, the administration of natalizumab $300 \mathrm{mg}$ IV every 4 weeks can be considered safe in pediatric patients with RRMS. Importantly, the PK profile, the a4-integrin saturation, and the increase in lymphocyte counts in this population are comparable to those reported in adult patients.

\section{Acknowledgment}

Editorial assistance for the preparation of this manuscript (technical editing) was provided by Luca Giacomelli, $\mathrm{PhD}$, and Ambra Corti, on behalf of Content Ed Net; this assistance was funded by Biogen.

\section{Study funding}

This study was supported by Biogen.

\section{Disclosure}

A. Ghezzi received fees for consultant and speaking activities from Merck, Novartis, Biogen, Genzyme, Teva, Roche, Almirall, and Mylan. Dr. Ghezzi has served on scientific advisory boards of Merck Serono, Sanofi-Genzyme, Novartis, Mylan, Biogen, and Teva and has received speaker honoraria from Merck Serono, Teva, Biogen Idec, SanofiGenzyme, Novartis, Serono Symposia International, and Almirall. G. Comi has received personal compensation for consulting and speaking activities from Biogen and Excemed. L.M. Grimaldi has received funding for travel to attend scientific events or speaker honoraria from Merck Serono, Biogen Idec, Sanofi-Aventis, Teva Pharmaceutical Industries Ltd., Roche, Novartis, and Bayer Schering Pharma and institutional research support from Biogen Idec and Serono Foundation. L. Moiola has received compensation for speaking or for participation to advisory board from Novartis, Roche, Sanofi-Genzyme, Biogen, Serono, and Teva. C. Pozzilli reports no disclosures. S. Frantaccini was an employee of Biogen Italia at the time of the study. P. Gallo reports no disclosures. Go to Neurology.org/NN for full disclosures.

\section{Publication history}

Received by Neurology: Neuroimmunology \& Neuroinflammation August 6, 2018. Accepted in final form May 24, 2019. 
Appendix Authors

\begin{tabular}{|c|c|c|c|}
\hline Name & Location & Role & Contributions \\
\hline $\begin{array}{l}\text { Angelo } \\
\text { Ghezzi, MD }\end{array}$ & $\begin{array}{l}\text { Gallarate Hospital } \\
\text { (VA), Italy }\end{array}$ & Author & $\begin{array}{l}\text { Designed the study, } \\
\text { coordinated the } \\
\text { conduction of the study, } \\
\text { recruited patients, } \\
\text { collected and analyzed } \\
\text { data, and wrote and } \\
\text { revised the manuscript }\end{array}$ \\
\hline
\end{tabular}

\begin{tabular}{|c|c|c|c|}
\hline $\begin{array}{l}\text { Giancarlo } \\
\text { Comi, MD }\end{array}$ & $\begin{array}{l}\text { San Raffaele } \\
\text { Scientific Institute, } \\
\text { Milan, Italy }\end{array}$ & Author & $\begin{array}{l}\text { Was one of the } \\
\text { investigators, enrolled } \\
\text { patients, revised data, } \\
\text { was involved in revision of } \\
\text { this manuscript, and } \\
\text { approved the submitted } \\
\text { version }\end{array}$ \\
\hline
\end{tabular}

\begin{tabular}{|c|c|c|c|}
\hline $\begin{array}{l}\text { Luigi Maria } \\
\text { Grimaldi, } \\
\text { MD }\end{array}$ & $\begin{array}{l}\text { Fondazione } \\
\text { Istituto San } \\
\text { Raffaele G. Giglio, } \\
\text { Cefalù, Italy }\end{array}$ & Author & $\begin{array}{l}\text { Was one of the } \\
\text { investigators, enrolled } \\
\text { patients, revised data, } \\
\text { was involved in revision of } \\
\text { this manuscript, and } \\
\text { approved the submitted } \\
\text { version }\end{array}$ \\
\hline
\end{tabular}

\begin{tabular}{lll}
\hline Lucia & San Raffaele & Author \\
Moiola, MD & Scientific Institute, & $\begin{array}{l}\text { Was one of the } \\
\text { investigators, enrolled } \\
\text { Milan, Italy }\end{array}$ \\
& patients, revised data, \\
& was involved in revision of \\
& this manuscript, and \\
& approved the submitted \\
& version
\end{tabular}

\begin{tabular}{|c|c|c|c|}
\hline $\begin{array}{l}\text { Carlo } \\
\text { Pozzilli, MD }\end{array}$ & $\begin{array}{l}\text { La Sapienza } \\
\text { University, Rome, } \\
\text { Italy }\end{array}$ & Author & $\begin{array}{l}\text { Was one of the } \\
\text { investigators, enrolled } \\
\text { patients, revised data, } \\
\text { was involved in revision of } \\
\text { this manuscript, and } \\
\text { approved the submitted } \\
\text { version }\end{array}$ \\
\hline
\end{tabular}

\begin{tabular}{|c|c|c|c|}
\hline $\begin{array}{l}\text { Simone } \\
\text { Fantaccini, } \\
\text { MD }\end{array}$ & $\begin{array}{l}\text { Biogen Italia, } \\
\text { Milan, Italy }\end{array}$ & Author & $\begin{array}{l}\text { Was one of the } \\
\text { investigators, enrolled } \\
\text { patients, revised data, } \\
\text { was involved in revision of } \\
\text { this manuscript, and } \\
\text { approved the submitted } \\
\text { version }\end{array}$ \\
\hline
\end{tabular}

\begin{tabular}{|c|c|c|c|}
\hline $\begin{array}{l}\text { Paolo } \\
\text { Gallo, MD }\end{array}$ & $\begin{array}{l}\text { Università degli } \\
\text { Studi di Padova, } \\
\text { Padova, Italy }\end{array}$ & Author & $\begin{array}{l}\text { Was one of the } \\
\text { investigators, enrolled } \\
\text { patients, revised data, } \\
\text { was involved in revision of } \\
\text { this manuscript, and } \\
\text { approved the submitted } \\
\text { version }\end{array}$ \\
\hline
\end{tabular}

\section{References}

1. Miller DH, Khan OA, Sheremata WA, et al. A controlled trial of natalizumab for relapsing multiple sclerosis. N Engl J Med 2003;348:15-23.

2. Polman $\mathrm{CH}$, O'Connor PW, Havrdova E, et al. A randomized, placebo-controlled trial of natalizumab for relapsing multiple sclerosis. N Engl J Med 2006;354:899-910.

3. Rudick RA, Stuart WH, Calabresi PA, et al. Natalizumab plus interferon beta-1a for relapsing multiple sclerosis. N Engl J Med 2006;354:911-923.
4. Natalizumab summary of product characteristics. Available at: ema.europa.eu/docs/ it_IT/document_library/EPAR_-_Product_Information/human/000603/ WC500044686.pdf. Accessed July 25, 2017.

5. Banwell B, Bar-Or A, Giovannoni G, Dale RC, Tardieu M. Therapies for multiple sclerosis: considerations in the pediatric patient. Nat Rev Neurol 2011;7; 109-122.

6. Ghezzi A, Banwell B, Boyko A, et al. The management of multiple sclerosis in children: a European view. Mult Scler 2010;16:1258-1267.

7. Ghezzi A, Pozzilli C, Grimaldi LM, et al. Safety and efficacy of natalizumab in children with multiple sclerosis. Neurology 2010;75:912-917.

8. Huppke P, Gärtner J. A practical guide to pediatric multiple sclerosis. Neuropediatrics 2010;41:157-162.

9. Yeh EA, Waubant E, Krupp LB, et al. Multiple sclerosis therapies in pediatric patients with refractory multiple sclerosis. Arch Neurol 2011;68:437-444.

10. Yeh EA, Weinstock-Guttman B. Natalizumab in pediatric multiple sclerosis patients. Ther Adv Neurol Disord 2010;3:293-299.

11. Ghezzi A, Amato MP, Makhani N, Shreiner T, Gärtner J, Tenembaum S. Pediatric multiple sclerosis: conventional first-line treatment and general management. Neurology 2016;87(suppl 2):S97-S102.

12. Chitnis T, Ghezzi A, Bajer-Kornek B, Boyko A, Giovannoni G, Pohl D. Pediatric multiple sclerosis: escalation and emerging treatments. Neurology 2016;87(9 suppl 2):S103-S109.

13. Aggiornamento dell'elenco dei medicinali, istituito con il provvedimento della Commissione Unica del Farmaco datato. 20 luglio 2000, erogabili a totale carico del Servizio sanitario nazionale, ai sensi della legge 23 dicembre 1996, n. 648; Official Gazette n. 118; May 23, 2011

14. Ghezzi A, Pozzilli C, Grimaldi LM, et al. Natalizumab in pediatric multiple sclerosis: results of a cohort of 55 cases. Mult Scler 2013;19:1106-1112.

15. Appleton RE, Boggild M. Natalizumab in paediatric multiple sclerosis and service implication. Dev Med Child Neurol 2009;51:758-759.

16. Borriello G, Prosperini L, Luchetti A, Pozzilli C. Natalizumab treatment in pediatric multiple sclerosis: a case report. Eur J Paediatr Neurol 2009;13:67-71.

17. Huppke P, Stark W, Zürcher C, Huppke B, Brück W, Gärtner J. Natalizumab use in pediatric multiple sclerosis. Arch Neurol 2008;65:1655-1658.

18. Putzki N, Stich O, Gartzen K, Kastrup O, Tettenborn B, Rauer S. Natalizumab treatment in paediatric multiple sclerosis: a case of induction, de-escalation and escalation. Eur J Neurol 2010;17:e105.

19. Kornek B, Aboul-Enein F, Rostasy K, et al. Natalizumab therapy for highly active pediatric multiple sclerosis. JAMA Neurol 2013;70:469-475.

20. Arnal-Garcia C, García-Montero MR, Málaga I, et al. Natalizumab use in pediatric patients with relapsing-remitting multiple sclerosis. Eur J Paediatr Neurol 2013;17: $50-54$.

21. Alroughani R, Ahmed SF, Behbehani R, Al-Hashel J. The use of natalizumab in pediatric patients with active relapsing multiple sclerosis: a prospective study. Pediatr Neurol 2017;70:56-60.

22. Ghezzi A, Moiola L, Pozzilli C, et al. Natalizumab in the pediatric MS population: results of the Italian registry. BMC Neurol 2015;15:174.

23. Hyams JS, Wilson DC, Thomas A, et al. Natalizumab therapy for moderate to severe Crohn disease in adolescents. J Pediatr Gastroenterol Nutr 2007;44:185-1891.

24. Ghezzi A, Pozzilli C, Moiola L, et al. Natalizumab in paediatric multiple sclerosis long-term results of 55 cases [poster]. Presented at the ECTRIMS 2012 28th Congress of the European Committee for Treatment and Research in Multiple Sclerosis October 10-13, 2012; Lyon, France.

25. Huppke P, Huppke B, Ellenberger D, et al. Therapy of highly active pediatric multiple sclerosis. Mult Scler 2019;25:72-80.

26. Chitnis T, Tardieu M, Amato MP, et al. International pediatric MS study group clinical trials summit: meeting report. Neurology 2013;80:1161-1168.

27. Ghezzi A. Randomized clinical trials (RCTs) in pediatric multiple sclerosis: are they really necessary? Mult Scler 2017;23:1042-1043.

28. Summary of product characteristics Tysabri ${ }^{\circledast}$. Available at: ema.europa.eu/en/documents/product-information/tysabri-epar-product-information_en.pdf. Accessed February 7, 2019.

29. Center for Drug Evaluation and Research. Clinical pharmacology and biopharmaceutics review, application number: 125104. Available at: accessdata.fda.gov/ drugsatfda_docs/nda/2004/125104s000_Natalizumab_Biopharmr.pdf. Accessed September 9, 2016.

30. Muralidharan KK, Kuesters G, Plavina T, et al. Population pharmacokinetics and target engagement of natalizumab in patients with multiple sclerosis. J Clin Pharmacol 2017;57:1017-1030.

31. Khatri BO, Man S, Giovannoni G, et al. Effect of plasma exchange in accelerating natalizumab clearance and restoring leukocyte function. Neurology 2009;72: 402-409. 


\title{
Neurology \\ Neuroimmunology \& Neuroinflammation
}

\author{
Pharmacokinetics and pharmacodynamics of natalizumab in pediatric patients with \\ RRMS \\ Angelo Ghezzi, Giancarlo Comi, Luigi Maria Grimaldi, et al. \\ Neurol Neuroimmunol Neuroinflamm 2019;6; \\ DOI 10.1212/NXI.0000000000000591
}

This information is current as of July 1, 2019

\section{Updated Information \& \\ Services \\ References \\ Subspecialty Collections}

Permissions \& Licensing

Reprints including high resolution figures, can be found at:

http://nn.neurology.org/content/6/5/e591.full.html

This article cites 26 articles, 0 of which you can access for free at: http://nn.neurology.org/content/6/5/e591.full.html\#\#ref-list-1

This article, along with others on similar topics, appears in the following collection(s):

All Pediatric

http://nn.neurology.org//cgi/collection/all_pediatric

Multiple sclerosis

http://nn.neurology.org//cgi/collection/multiple_sclerosis

Patient safety

http://nn.neurology.org//cgi/collection/patient_safety

Information about reproducing this article in parts (figures,tables) or in its entirety can be found online at:

http://nn.neurology.org/misc/about.xhtml\#permissions

Information about ordering reprints can be found online:

http://nn.neurology.org/misc/addir.xhtml\#reprintsus

Neurol Neuroimmunol Neuroinflamm is an official journal of the American Academy of Neurology.

Published since April 2014, it is an open-access, online-only, continuous publication journal. Copyright

Copyright $\odot 2019$ The Author(s). Published by Wolters Kluwer Health, Inc. on behalf of the American

Academy of Neurology.. All rights reserved. Online ISSN: 2332-7812.

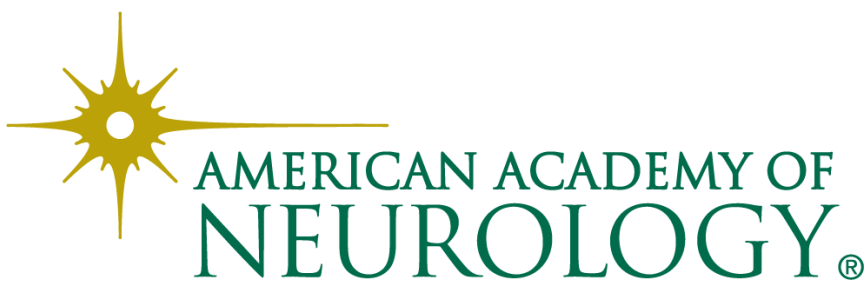

